\title{
Growth retardants in wheat and its effect in physiological quality of seeds
}

\author{
Redutores de crescimento em plantas de trigo e seus efeitos na qualidade fisiológica de sementes
}

\author{
Leandro Torres de Souza ${ }^{\mathrm{I} *}$ Marcelo Curitiba EspíndulaII Valterley Soares Rocha ${ }^{\mathrm{II}}$ \\ Denise Cunha Fernandes dos Santos Dias" Moacil Alves de Souza ${ }^{\text {II }}$
}

\section{ABSTRACT}

Plant lodging in wheat has been controlled through growth retardants. However, there is lack of information on the effect of these products on the physiological quality of seeds. The objective of this study was to evaluate the physiological quality of wheat seeds obtained under different rates and application times of three growth retardants. The trial was carried out in Viçosa-MG, from May to September 2005, in a factorial and hierarchical scheme, in randomized block design with four replications and a control treatment. The treatments consisted of 500, 1000 and $1500 \mathrm{~g} \mathrm{ha}^{-1}$ of chlormequat; 40, 80 and $120 \mathrm{~g} \mathrm{ha}^{-1}$ of paclobutrazol and 62.5, 125 and $187.5 \mathrm{~g} \mathrm{ha}$ ${ }^{1}$ of trinexapac-ethyl applied at the 6 or 8 growth stage based on the scale of Feeks and Large, and a control treatment without growth retardant application. Leaf application of growth retardants as chlormequat, paclobutrazol and trinexapac-ethyl did not affect the germination and vigor of wheat seeds.
\end{abstract}

- NOTE -
Key words: Triticum aestivum, chlormequat, paclobutrazol, trinexapac-ethyl, germination and vigor.

\section{RESUMO}

O acamamento de plantas na cultura do trigo tem sido controlado com o uso de redutores de crescimento. No entanto, há carência de informações sobre o efeito desses produtos na qualidade fisiológica de sementes. O objetivo deste estudo foi avaliar a qualidade fisiológica das sementes de trigo obtidas sob efeito de doses e épocas de aplicação de três redutores de crescimento. O experimento, conduzido em Viçosa, Minas Gerais, entre maio e setembro de 2005, foi instalado com tratamentos em esquema fatorial e hierárquico com uma testemunha, no delineamento em blocos casualizados, com quatro repetições. Os tratamentos foram 500, 1000 e $1500 \mathrm{~g}$ $\mathrm{ha}^{-1}$ de clormequat; 40, 80 e $120 \mathrm{~g} \mathrm{ha}^{-1}$ de paclobutrazol e
62,5, 125 e 187,5g ha-1 de trinexapac-etil aplicados no estádio 6 ou 8 da escala Feeks e Large, mais uma testemunha sem aplicação de redutor. A aplicação foliar dos redutores de crescimento clormequat, paclobutrazol e trinexapac-etil não afeta a germinação e o vigor das sementes de trigo.

Palavras-chave: Triticum aestivum, clormequat, paclobutrazol, trinexapac-etil, germinação e vigor.

Lodging in wheat is commonly reduced by using resistant cultivars, restricting nitrogen fertilizer application or irrigation management in critic periods. But, this problem can also be solved by the application of growth retardants, which besides reducing plant size, allows better nutrient utilization by the plant in response to physiological changes (BUZETTI et al., 2006, ESPINDULA et al., 2009a).

Growth retardants reduce plant lodging and improve plant architecture increasing efficiency in capturing solar radiation and other environmental resources (ZAGONEL \& FERNANDES, 2007). These effects can change assimilate partition, improving seed filling and, consequently, the physiological quality of seeds (SAWAN et al., 2009). However, high doses of these products may promote excessive shoot reduction (ESPINDULA et al., 2009b) and spike retention (ZAGONEL \& FERNANDES, 2007), causing reduction in seed filling. Furthermore, growth retardants, which mainly affect the gibberellin synthesis, may reduce $\mathrm{GA}_{1}$

IDepartamento de Fisiologia Vegetal, Universidade Federal de Viçosa (UFV), 36570-000, Viçosa, MG, Brasil. E-mail: souzalts@yahoo.com.br.*Autor para correspondência.

"Departamento de Fitotecnia, UFV, Viçosa, MG, Brasil. 
levels in wheat seeds (RADEMACHER, 2000) and act on other metabolic pathways (HECKMAN et al., 2002, HAJIHASHEMI et al., 2007) promoting effects still not clear on plant development. Thus, it is believed that the effect of retardants on plant growth and development can reflect changes in the physiological quality of wheat seeds. The objective of this study was to evaluate the physiological quality of wheat seeds obtained under different doses and times of application of three growth retardants.

The field experiment was conducted at the Experimental Station Diogo Alves de Mello, of the Universidade Federal de Viçosa, from May to September 2005. Soil preparation consisted of plowing followed by two disk harrowing and fertilization with $250 \mathrm{~kg} \mathrm{ha}^{-1}$ of a 8-28-16 formula at sowing and $40 \mathrm{~kg} \mathrm{ha}^{-1}$ $\mathrm{N}$ as topdressing at early tilling (15 days after emergence), with cultivar Pioneiro (intermediate height and moderate resistance to lodging).

The experiment was set up in a factorial and hierarchical scheme, in a randomized block design with four replications and a control treatment. The treatments consisted of three growth retardants: 1) chlormequat (2-chloroethyl trimethylammonium chloride) (Cycocel $\left.^{\circledR}\right)$; 2) paclobutrazol [(2RS,3RS)-1-(4chlorophenyl)-4,4-dimethyl-2-(1H-1,2,4-triazol-1yl)pentan-3-ol] (Cultar $\left.{ }^{\circledR}\right)$ and 3) Trinexapac-ethyl (4c y c lopropryl (hydroxy) methylene-3,5dioxocyclohexane ethyl carboxilate) (Moddus ${ }^{\circledR}$ ). Three doses (500, 1000 and 1500g ha ${ }^{-1}$ of chlormequat, 40, 80 and $120 \mathrm{~g} \mathrm{ha}^{-1}$ of paclobutrazol and 62.5, 125 and $187.5 \mathrm{~g}$ ha $^{-1}$ of trinexapac-ethyl) and two application times, the first at stage 6 of the scale Feeks (LARGE, 1954), when the plants are in flower differentiation, with the first visible node, or at stage 8 with plants with the second node already formed, and a control treatment without retardant application.

Retardant applications were carried out 24 or 34 days after seedling emergence, for time 1 and 2 respectively, using a $\mathrm{CO}_{2}$ backpack sprayer, at constant pressure of $2,039 \mathrm{kgf}^{-2}$, with two $0.5 \mathrm{~m}$ spaced fan nozzles (XR 110-015). A volume of 150 $\mathrm{L} \mathrm{ha}^{-1}$ of growth retardant solution was applied. Each plot consisted of five rows of $5 \mathrm{~m}$ length spaced $0.184 \mathrm{~m}$ apart. The plot usable area $\left(2.2 \mathrm{~m}^{2}\right)$ was formed by the three central rows, disconsidering $50 \mathrm{~cm}$ at both ends of the plot.

Harvest was carried out at the end of the crop cycle (September 2005), when the seeds had 13\% moisture. Seeds were cleaned and stored in permeable paper packaging and sent to laboratory for physiological quality analysis. The statistical design of the laboratory experiment followed the same scheme of the field experiment.
Seed physiological quality was analyzed by germination (BRASIL, 1992) and vigor tests [first germination count and accelerating aging (LIMA et al., 2006)], both at the Laboratory of Seed Analysis, Agronomy Department - UFV, as well as the field emergence test was carried out at the Experimental Station Diogo Alves de Mello, Agronomy Department of the same university. The field emergence test was carried out using 100 seeds for each plot with four replicates in a randomized block design. Seeds were sown in $1 \mathrm{~m}$ furrows, $40 \mathrm{~cm}$ spacing and $3 \mathrm{~cm}$ depth. Counting of seedlings was performed daily, from the first emerged seedling over a period of 13 days, to obtain a constant number of seedlings in each plot. The results were expressed in percentage and emergence speed index, according to (MAGUIRE, 1962). Data were examined for normality and variance homogeneity to verify the need for transformation, and then analysis of variance was performed.

Wheat seed germination and vigor were not affected by growth retardant applications at any studied doses or times (Table 1). These results may be related to the non occurrence of plant lodging in all treatments. The effect of plant lodging on the physiological quality of seeds is expected because: 1) when it happens at the seed filling stage, it will limit photosynthesis due to plant shading caused by the upper layer plants over the lower layers (SETTER et al., 1997), and translocation of photoassimilates, because there may occur rupture or strangulation of the conductive vessels at the curvature of the stem, hindering the sap flow in these structures; 2) when it happens at maturity, the lodged plants have their spikes lying near the ground, in a more humid environment, resulting in decrease in hectoliter weight and germination, as well as seed decay (ZAGONEL \& FERNANDES, 2007).

Retardants may also decrease vegetative biomass and lead to reduction in seed filling. This reduction in leaf area can reduce the plant photosynthetic area, while the reduction in stem mass can reduce the amount of reserves accumulated for translocation at seed filling (ESPINDULA et al., 2009b). On the other hand, growth retardants may cause morphological changes when reducing plant height, providing them with more suitable architecture for utilizing the environmental resources (ZAGONEL \& FERNANDES, 2007). Although these changes have not been evaluated, the results suggest that they were not enough to alter the physiological quality of seeds, or, still, it is possible that the effects of an alteration may have canceled the other.

Another possible interference would be a direct action of the product on seed filling and 
Table 1 - Means of physiological quality characteristics of wheat seeds, cultivar Pioneiro, subjected to three doses of three growth retardants applied in two times (Time 1 or 2 = stage 6 hor 8 of the Feeks and Large scale).

\begin{tabular}{|c|c|c|c|c|c|c|c|}
\hline \multirow[b]{2}{*}{ Treatments $^{1}$} & & & \multicolumn{2}{|c|}{ Germination test } & \multirow{2}{*}{$\begin{array}{l}\text { Accelerating aging } \\
\text { Normal plants }\end{array}$} & \multicolumn{2}{|c|}{ Emergence in the field } \\
\hline & & & First count & Normal plants & & Emergence & IVE \\
\hline \multirow{8}{*}{ Chlormequat } & Time & Dose $\left(\mathrm{g} \mathrm{ha}^{-1}\right)$ & ------------- & ----------------- & --\%-------------------- & ----------- & \\
\hline & & 500 & 61.5 & 74.5 & 59.0 & 54.7 & 9.9 \\
\hline & Time 1 & 1000 & 58.2 & 72.5 & 58.5 & 55.8 & 10.6 \\
\hline & & 1500 & 55.5 & 70.2 & 61.0 & 51.5 & 9.5 \\
\hline & & 500 & 65.7 & 79.7 & 54.2 & 55.7 & 10.1 \\
\hline & Time 2 & 1000 & 54.7 & 74.2 & 57.3 & 53.7 & 9.9 \\
\hline & & 1500 & 57.7 & 73.2 & 60.2 & 49.9 & 10.0 \\
\hline & & 40 & 56.0 & 72.7 & 60.0 & 50.2 & 9.6 \\
\hline \multirow{7}{*}{ Paclobutrazol } & Time 1 & 80 & 62.0 & 79.0 & 58.5 & 56.2 & 10.3 \\
\hline & & 120 & 63.2 & 76.5 & 61.2 & 53.7 & 10.0 \\
\hline & & 40 & 61.5 & 78.5 & 59.2 & 51.1 & 9.8 \\
\hline & Time 2 & 80 & 53.7 & 67.2 & 62.0 & 58.7 & 10.1 \\
\hline & & 120 & 58.5 & 71.7 & 64.2 & 61.2 & 10.9 \\
\hline & & 62.5 & 60.7 & 75.2 & 61.3 & 52.4 & 10.5 \\
\hline & Time 1 & 125 & 57.0 & 74.0 & 62.3 & 51.7 & 9.6 \\
\hline \multirow{4}{*}{ Trinexapac-etil } & & 187.5 & 53.5 & 72.0 & 58.7 & 51.7 & 9.2 \\
\hline & & 62.5 & 58.0 & 75.0 & 59.7 & 53.2 & 9.8 \\
\hline & Time 2 & 125 & 53.7 & 70.5 & 51.5 & 55.7 & 10.2 \\
\hline & & 187.5 & 53.2 & 65.2 & 50.7 & 49.5 & 10.2 \\
\hline Control & & 0.0 & 54.5 & 67.2 & 53.5 & 51.7 & 9.5 \\
\hline Mean & & & 57.8 & 73.1 & 58.6 & 53.6 & 10.0 \\
\hline VC (\%) & & & 10.1 & 6.8 & 10.3 & 18.5 & 17.8 \\
\hline
\end{tabular}

${ }^{1}$ Non significant effects for any factor or interaction of factors.

germination. This could happen because growth retardants may act on metabolic pathways other than the gibberellin synthesis. Changes caused by growth retardants on the plant metabolism include the effect of trinexapac-ethyl on respiration (HECKMAN et al., 2002), changes in nutrient content of tissues by paclobutrazol (HAJIHASHEMI et al., 2007), increased level of cytokinin and the consequent increase in cell division by paclobutrazol (GOPI et al., 2005), reduction of ethylene levels by inhibition of ACC oxidase (RADEMACHER, 2000), among others. However, the results suggest that even if these effects occurred, they were not enough to compromise the plant reproductive phase. In addition, the results also suggest that the de novo synthesis of gibberellin during germination is not affected, confirming the absence of residual effect of the products on seeds.

The results allowed the conclusion that foliar application of the growth retardants chlormequat, paclobutrazol and trinexapac-ethyl did not affect the physiological quality of wheat seeds.

\section{ACKNOWLEDGMENTS}

The authors would like to thank the Conselho Nacional de Desenvolvimento Científico e Tecnológico (CNPq) and Fundação de Amparo a Pesquisa do Estado de Minas Gerais (FAPEMIG) for the financial support.

\section{REFERENCES}

BRASIL, Ministério da Agricultura e Reforma Agrária. Regras para análise de sementes. Brasília: SNDA/DNPV/CLAV, 1992. 365p.

BUZETTI, S. et al. Resposta de cultivares de arroz a doses de nitrogênio e do regulador de crescimento cloreto de clormequat. Pesquisa Agropecuária Brasileira, v.41, p.1731-1737, 2006. Available from: < http://www.scielo.br/pdf/pab/v41n12/ a07v4112.pdf>. Accessed: Jan. 21, 2010. doi: 10.1590/S0100204X2006001200007.

ESPINDULA, M.C. et al. Effect of nitrogen and trinexapacethyl rates on the SPAD index of wheat leaves. Journal of Plant Nutrition, v.32, p.1956-1964, 2009a. 
ESPINDULA, M.C. et al. Use of growth retardants in wheat. Planta Daninha, v.27, p.379-387, 2009b. Available from: <http://www.scielo.br/pdf/pd/v27n2/22.pdf>. Accessed: Jan. 21, 2010. doi: 10.1590/S0100-83582009000200022.

GOPI, R. et al. Growth and photosynthetic characteristics as affected by triazoles in Amorphophallus campanulatus Blume. General and Applied Plant Physiology, v.31, p.171-180, 2005. Available from: <http://www.bio21.bas.bg/ipp/gapbfiles/ v-31/05_3-4_171-180.pdf>. Accessed: Jan. 21, 2010.

HAJIHASHEMI, S. et al. Exogenously applied paclobutrazol modulates growth in salt-stressed wheat plants. Plant Growth Regul, v.53, p.117-128, 2007. Available from: <http:// www.springerlink.com/content/c367438g8038g408/ fulltext.pdf $>$. Accessed: Jan. 21, 2010. doi: 10.1007/s10725007-9209-8.

HECKMAN, N.L. et al. Influence of trinexapac-ethyl on respiration of isolated wheat mitochondria. Crop Science, v.42, p.423-427, 2002. Available from: <http://crop.scijournals.org/cgi/ reprint/42/2/423>. Accessed: Jan. 21, 2010.

LARGE, E.C. Growth stages in cereals - illustration of the feekes scale. Plant Pathology, v.3, p.128-129, 1954. Available from: <http://www3.interscience.wiley.com/cgi-bin/fulltext/ 119780630/PDFSTART>. Accessed: Jan. 21, 2010.

LIMA, T.C. et al. Avaliação do vigor de sementes de trigo pelo teste de envelhecimento acelerado. Revista Brasileira de
Sementes, v.28, p.106-113, 2006. Available from: <http:// www.scielo.br/pdf/rbs/v28n1/a15v28n1.pdf>. Accessed: Jan. 21, 2010. doi: 10.1590/S0101-31222006000100015.

MAGUIRE, J.D. Speeds of germination-aid selection and evaluation for seedling emergence and vigor. Crop Science, v.2, p.176-7, 1962.

RADEMACHER, W. Growth retardants: effects on gibberellin biosynthesis and other metabolic pathways. Annual Review of Plant Physiology and Plant Molecular Biology, v.51, p.50131, 2000. Available from: <http://arjournals.annualreviews.org/ doi/abs/10.1146\%2Fannurev.arplant.51.1.501>. Accessed: Jan. 26, 2010.

SAWAN, Z.M. et al. Direct and residual effects of nitrogen fertilization, foliar application of potassium and plant growth retardant on Egyptian cotton growth, seed yield, seed viability and seedling vigor. Acta Ecologica Sinica, v.29, p.116-123, 2009.

SETTER et al. Lodging reduces yield of rice by self-shading and reductions incanopy photosynthesis. Field Crops Research, v.49, p.95-106, 1997.

ZAGONEL, J.; FERNANDES, E.C. Doses e épocas de aplicação do redutor de crescimento afetando cultivares de trigo em duas doses de nitrogênio. Planta Daninha, v.25, p.331-339, 2007. Available from: <http://www.scielo.br/pdf/pd/v25n2/a13v25n2.pdf>. Accessed: Jan. 21, 2010. doi: 10.1590/S0100-83582007000200013. 